\title{
Bioflocculation potentials of a uronic acid-containing glycoprotein produced by Bacillus sp. AEMREG4 isolated from Tyhume River, South Africa
}

\author{
Nozipho Ntsangani ${ }^{1,2} \cdot$ Kunle Okaiyeto $^{1,2} \cdot$ Nwodo U. Uchechukwu $^{1,2}$. \\ Ademola O. Olaniran ${ }^{3}$ Leonard V. Mabinya ${ }^{1,2} \cdot$ Anthony I. Okoh ${ }^{1,2}$
}

Received: 16 February 2017/ Accepted: 15 March 2017/Published online: 12 May 2017

(c) The Author(s) 2017. This article is an open access publication

\begin{abstract}
Bioflocculants are secondary metabolites produced by microorganisms during their growth which have received attentions due to their biodegradability, innocuousness and lack of secondary pollution from degradation intermediates. This study reports on a bioflocculant produced by Bacillus specie isolated from Thyume River in South Africa. The bacterial isolate was identified through $16 \mathrm{~S}$ rDNA sequencing and the BLAST analysis of the nucleotide sequences revealed $99 \%$ similarity to Bacillus sp. BCT-7112. The sequence was subsequently deposited in the GenBank as Bacillus sp. AEMREG4 with accession number KP406729. The optimum culture conditions for bioflocculant production were an inoculum size $4 \%(\mathrm{v} / \mathrm{v})$ $(80 \%)$ and starch $(81 \%)$ as well as yeast extract $(82 \%)$ as sole carbon and nitrogen sources, respectively. Addition of $\mathrm{Ca}^{2+}$ greatly enhanced the flocculating activity $(76 \%)$ of crude bioflocculant over a wide range of $\mathrm{pH} 4-10$ and retained high flocculating activity when heated at $100{ }^{\circ} \mathrm{C}$ for $1 \mathrm{~h}$. Chemical analyses of the purified bioflocculant revealed carbohydrate $(79 \% \mathrm{w} / \mathrm{w})$ as a predominant component followed by uronic acid $(15 \% \mathrm{w} / \mathrm{w})$ and protein $(5 \%$
\end{abstract}

Kunle Okaiyeto

kokaiyeto@ufh.ac.za

Nwodo U. Uchechukwu

UNwodo@ufh.ac.za

1 SAMRC Microbial Water Quality Monitoring Centre, University of Fort Hare, Alice 5700, South Africa

2 Applied and Environmental Microbiology Research Group (AEMREG), Department of Biochemistry and Microbiology, University of Fort Hare, Alice 5700, South Africa

3 Department of Microbiology, School of Life Sciences, University of KwaZulu-Natal, Private Bag X54001, Durban 4000, South Africa w/w). Fourier transform infrared spectrum revealed the presence of carboxyl, hydroxyl and methoxyl groups as the functional groups responsible for flocculation and the high flocculation activity achieved portends its industrial applicability.

Keywords Bacillus sp. AEMREG4 - Uronic acidcontaining glycoprotein - Flocculating activity . Thermostable

\section{Introduction}

Flocculants are substances of either synthetic or natural origin used as sedimentation aids to bring about the solidliquid separations by the process of flocculation (Lachhwani 2005). They are conventionally used in different industrial processes such as water treatment, downstream processing in fermentation processes and mineral ore treatment in metallurgical industries (Nwodo et al. 2013). Flocculants can either be cationic or anionic with respect to charge and they also exhibit a wide range of the molecular weights (Salehizadeh and Shojaosadati 2001). However, their setbacks include the hazard impose to human health such as neurotoxicity and carcinogenicity in humans (Dearfield et al. 1988). It has also been reported that aluminium, the main constituent of polyaluminum may lead to the development of Alzheimer's disease (Arezoo 2002). Chemical flocculants such as polyacrylamides have also been reported to be recalcitrant to degradation (Mabinya et al. 2011; Piyo et al. 2011). Hence, the need for better alternatives that are safe and environmentally friendly and bioflocculants appear to be an important candidate to fill in the gap (Cosa et al. 2011). 
Previous studies have confirmed the effectiveness of bioflocculants in the removal of humic acids, treatment of dye solutions, wastewater treatment and the removal of metal ions from aqueous solution (Salehizadeh and Shojaosadati 2003; Zouboulis et al. 2004; Deng et al. 2005; Liu et al. 2009). However, high production costs accompanied by low yield have been the major drawbacks to large-scale production for industrial applications; thus, prompting the need for new microorganisms with enhanced bioflocculantproducing capability that justify the production costs. In this paper, we report on the flocculating potential of a bioflocculant produced by Bacillus sp. AEMREG4 isolated from water samples from Tyhume River in the Eastern Cape Province, South Africa.

\section{Materials and methods}

\section{Isolation and identification of bioflocculant- producing bacteria}

The bacterial isolate was recovered from water samples collected from Tyhume River in the Eastern Cape Province, South Africa, screened for bioflocculant production and identified in accordance with our previous studies (Cosa and Okoh 2014; Nwodo et al. 2014; Ugbenyen and Okoh 2014). Briefly, seed culture of the bacterial isolate was prepared from the $20 \% \mathrm{v} / \mathrm{v}$ glycerol stock by inoculating $5 \mu \mathrm{l}$ of the pure culture into $5 \mathrm{ml}$ of the activation medium (Makapela et al. 2016), and incubated on a rotary shaker at $160 \mathrm{rpm}, 28{ }^{\circ} \mathrm{C}$ for $24 \mathrm{~h}$. The compositions of the growth medium contained the following: glucose $20 \mathrm{~g}$, urea $0.5 \mathrm{~g}$, yeast extract $0.5 \mathrm{~g},\left(\mathrm{NH}_{4}\right)_{2} \mathrm{SO}_{4} 0.2 \mathrm{~g}, \mathrm{~K}_{2} \mathrm{HPO}_{4}$ $5 \mathrm{~g}, \mathrm{KH}_{2} \mathrm{PO}_{4} 2 \mathrm{~g}, \mathrm{NaCl} 0.1 \mathrm{~g}$ and $\mathrm{MgSO}_{4} \cdot 7 \mathrm{H}_{2} \mathrm{O} 0.2 \mathrm{~g}$ in 11 of distilled water (Nwodo et al. 2014). After $24 \mathrm{~h}$ of incubation, $2 \mathrm{ml}$ of the seed culture was inoculated into $50 \mathrm{ml}$ of growth medium and incubated on a rotary shaker at $160 \mathrm{rpm}, 28^{\circ} \mathrm{C}$ for $72 \mathrm{~h}$. Thereafter, cell-free supernatant of the culture was obtained by centrifugation at $4000 \times g, 4{ }^{\circ} \mathrm{C}$ for $30 \mathrm{~min}$ and used to determine the flocculating activity.

\section{Determination of flocculating activity}

A suspension of Kaolin (4 g/l) (Merck, Germany) was used as test material for estimating flocculating activity of the produced bioflocculant as described by Kurane et al. (1994). One hundred millilitres of clay suspension $(100 \mathrm{ml}), 3 \mathrm{ml}$ of $\mathrm{CaCl}_{2}(1 \% \mathrm{w} / \mathrm{v})$ and $2 \mathrm{ml}$ of the culture supernatant were mixed together by agitation for $60 \mathrm{~s}$ in 250-ml conical flask and subsequently transferred into a 100-ml graduated cylinder, allowed to sediment for $5 \mathrm{~min}$ at room temperature. The control was also prepared similarly except for the bioflocculant which was replaced with a freshly prepared medium. The optical density (OD) of the clarifying supernatant was measured at $550 \mathrm{~nm}$ with a UV spectrophotometer (Thermo Spectronic, Heliox Epsilon, New York, USA) and the flocculating activity was calculated using the following formula:

Flocculating activity $(\%)=(\mathrm{A}-\mathrm{B} / \mathrm{A}) \times 100$,

where A and B are optical densities of the control and sample, measured at $550 \mathrm{~nm}$, respectively.

\section{Effect of inoculum size on bioflocculant production}

The effect of inoculum size on bioflocculant production was assessed by varying the amounts of seed culture ranging from 1 to $5 \%(\mathrm{v} / \mathrm{v})$ into a production medium as described by Ugbenyen et al. (2012). The cell-free supernatants were analysed for flocculating activity.

\section{Effect of carbon and nitrogen sources on bioflocculant production}

The effect of various carbon and nitrogen sources on bioflocculant production was investigated in accordance with the method described by Ugbenyen et al. (2012). The seed culture was inoculated into growth medium contained in separate flasks supplemented with different carbon sources and incubated in a rotary shaker at $160 \mathrm{rpm}, 28^{\circ} \mathrm{C}$ for $120 \mathrm{~h}$. The carbon source candidates included: glucose, fructose, maltose, lactose, sucrose and starch. Likewise, the nitrogen sources included: tryptone, peptone, urea, yeast extract (organic nitrogen sources) and ammonium sulphate (inorganic nitrogen source). The flocculating activity was determined after the cultivation period as described elsewhere.

\section{Effect of initial pH of growth medium}

The effect of initial $\mathrm{pH}$ of the growth medium on bioflocculant production was examined by varying the $\mathrm{pH}$ of the production medium between the $\mathrm{pH}$ ranges of 4-10 using $\mathrm{NaOH}(0.1 \mathrm{M})$ or $\mathrm{HCl}(0.1 \mathrm{M})$ (Yim et al. 2007). The media were incubated in a rotary shaker at $160 \mathrm{rpm}, 28^{\circ} \mathrm{C}$ for $120 \mathrm{~h}$ after which flocculating activity was determined as previously described.

\section{Effect of cations on flocculating activity of crude bioflocculant}

The effect of cations on the flocculating activity of crude bioflocculant was assessed following the same procedure as described elsewhere for determining flocculating activity; however, $\mathrm{CaCl}_{2}$ solution (1\% w/v) used in the flocculating 
assay was replaced by various metal ion solutions prior to measuring flocculating activity. Solutions of $\mathrm{NaCl}, \mathrm{KCl}$ (monovalent cations), $\mathrm{MgCl}_{2}, \mathrm{MnCl}_{2} \cdot 4 \mathrm{H}_{2} \mathrm{O}, \mathrm{CaCl}_{2}$ (divalent cations), $\mathrm{AlCl}_{3}$ and $\mathrm{FeCl}_{3} \cdot 6 \mathrm{H}_{2} \mathrm{O}$ (trivalent cations) were used as cation sources (Liu et al. 2010) and flocculating activity was measured as previously described.

\section{Time course of bioflocculant production}

\section{Composition of culture medium}

The optimum culture conditions for bioflocculant production were used for the time course assay as described by Okaiyeto et al. (2013). The medium compositions contained the following in 1 litre of distilled water: glucose $20 \mathrm{~g}$, urea $0.5 \mathrm{~g}$, yeast extract $0.5 \mathrm{~g},\left(\mathrm{NH}_{4}\right)_{2} \mathrm{SO}_{4} 0.2 \mathrm{~g}$, $\mathrm{K}_{2} \mathrm{HPO}_{4} 5 \mathrm{~g}, \mathrm{KH}_{2} \mathrm{PO}_{4} 2 \mathrm{~g}, \mathrm{NaCl} 0.1 \mathrm{~g}$ and $\mathrm{MgSO}_{4} \cdot 7 \mathrm{H}_{2} \mathrm{O}$ $0.2 \mathrm{~g}$. The $\mathrm{pH}$ was adjusted to $\mathrm{pH} 8$ with either $\mathrm{NaOH}$ or $\mathrm{HCl}(0.1 \mathrm{M})$.

\section{Standardization of inocula}

For inoculum preparation, two loopful of the bacterial isolate from nutrient agar plate (Merck, South Africa) was inoculated into $50 \mathrm{~mL}$ of activation medium (beef extract $3 \mathrm{~g}$, tryptone $10 \mathrm{~g}, \mathrm{NaCl} 5 \mathrm{~g}$ in 1 litre of distilled water) in a 250-ml flask incubated on a rotary shaker at $160 \mathrm{rpm}, 28^{\circ} \mathrm{C}$, for $24 \mathrm{~h}$. After the cultivation period, distilled water was used to adjust the turbidity of the fermented broth to an optical density $0.1\left(\mathrm{OD}_{600}\right)$ (Okaiyeto et al. 2015). The standardized bacterial suspension was inoculated into $200 \mathrm{ml}$ of production medium and incubated in a rotary shaker at $160 \mathrm{rpm}, 28^{\circ} \mathrm{C}$. Medium samples $(15 \mathrm{ml})$ were withdrawn at 24-h intervals for a period of $120 \mathrm{~h}$ and monitored for cell growth, $\mathrm{pH}$, and flocculating activity. Two millilitres of culture broth was centrifuged at $4000 \times g, 4{ }^{\circ} \mathrm{C}$ for $30 \mathrm{~min}$, and the cell-free supernatant was used as the crude bioflocculant to determine the flocculating activity. The bacterial growth was monitored by measuring the viable counts using standard spread plate technique and nutrient agar and all plates were incubated at $37^{\circ} \mathrm{C}$ for $36 \mathrm{~h}$.

\section{Extraction and purification of bioflocculant}

After $120 \mathrm{~h}$ of fermentation, the fermented broth was centrifuged at $4000 \times g, 4{ }^{\circ} \mathrm{C}$ for $30 \mathrm{~min}$ to remove cells and cell debris. The supernatant was diluted with 11 of sterile distilled water and the mixture was centrifuged at $4000 \times g, 4{ }^{\circ} \mathrm{C}$ for $15 \mathrm{~min}$ to remove all the insoluble substances. Two volumes of cold ethanol were added to the supernatant and the mixture was stirred and left standing at $4{ }^{\circ} \mathrm{C}$ for $12 \mathrm{~h}$ for precipitation. The supernatant was discarded and the precipitate was vacuum-dried to obtain the crude biopolymer following the modified method of Zhang et al. (2010). The obtained precipitate was re-dissolved in distilled water $(1 \% \mathrm{w} / \mathrm{v})$ followed by the addition of one volume of a mixture of chloroform and n-butyl alcohol (5:2 $\mathrm{v} / \mathrm{v})$ with stirring. The mixture was then left standing at room temperature for $12 \mathrm{~h}$ and the upper phase was centrifuged at $4000 \times g, 4{ }^{\circ} \mathrm{C}$ for $15 \mathrm{~min}$ and thereafter, the supernatant was dialyzed overnight against distilled water. The dialysate was then vacuum-dried to obtain a purified bioflocculant.

\section{Characterization of the purified bioflocculant}

The total protein content was measured by Folin-Lowry method as elaborated by Lowry et al. (1961) using bovine serum albumin (BSA) as the standard solution. The total sugar content of the purified bioflocculant was determined using the phenol-sulfuric acid method with glucose as the standard solution as described by Chaplin and Kennedy (1994). Potassium bromide (KBr) powder was ground with the dried bioflocculant before pressing it into pellets for Fourier transform infrared (FTIR) (Perkin Elmer System 2000, FT-IR, Middlesex, England) spectroscopy analysis over a wavelength range of $4000-370 \mathrm{~cm}^{-1}$ (He et al. 2010). The scanning electron microscopy (SEM) (JSM6390LV, JEOL, Tokyo, Japan) imaging of the bioflocculant and the Kaolin clay particles was also examined (Xiong et al. 2010).

\section{Thermal stability of purified bioflocculant}

Thermal stability of purified bioflocculant was carried out according to the method described by Okaiyeto et al. (2013). The bioflocculant solutions were incubated at various temperatures ranging from 50 to $100{ }^{\circ} \mathrm{C}$ for a period of $1 \mathrm{~h}$ prior to measuring residual flocculating activity at room temperature.

\section{Effect of $\mathrm{pH}$ and cations on the flocculating activity of purified bioflocculant}

The effect of $\mathrm{pH}$ on the flocculating activity was determined by adjusting the $\mathrm{pH}$ of Kaolin clay suspension in a separate $250-\mathrm{ml}$ flask and the $\mathrm{pH}$ values of the suspension ranging between 3 and 10 were adjusted using either $\mathrm{HCl}$ or $\mathrm{NaOH}(0.1 \mathrm{M})$ and thereafter, the flocculating activity of each suspension at different $\mathrm{pH}$ value was determined as previously described (Kurane et al. 1994). The effect of cations on the flocculating activity of purified bioflocculant was determined by replacing $\mathrm{CaCl}_{2}(1 \% \mathrm{w} / \mathrm{v})$ with each of the following salt solutions: $\mathrm{NaCl}, \mathrm{KCl}$ (monovalent cations), $\mathrm{MgCl}_{2}, \mathrm{MnCl}_{2} \cdot 4 \mathrm{H}_{2} \mathrm{O}$ (divalent cations), $\mathrm{AlCl}_{3}$ and $\mathrm{FeCl}_{3} \cdot 6 \mathrm{H}_{2} \mathrm{O}$ (trivalent cations) as cation sources (He et al. 
2010; Liu et al. 2010). The flocculating activity was determined as previously described.

\section{Statistical analysis}

All data were treated in triplicate and the mean values were taken. Data were subjected to one-way analysis of variance (ANOVA) using the MINITAB Student Release 12 statistical package for Windows 95/98 NT (Minitab Inc., State College, PA, USA, 2007).

\section{Results and discussion}

\section{Isolation and identification of bioflocculant- producing bacteria}

The test bacterium is Gram-positive with a circular-shaped cream coloured colonial morphology on nutrient agar. The $16 \mathrm{~S}$ rDNA nucleotide sequence analyses of the bacterial isolate revealed it to have $99 \%$ similarity to Bacillus sp. BCT-7112. The nucleotide sequence was then deposited in GenBank as Bacillus sp. AEMREG4 with accession number KP406729. Quite number of Bacillus species have been reported to produce bioflocculants and these include Bacillus mucilaginosus (Deng et al. 2003), Bacillus licheniformis X14 (Li et al. 2009), Bacillus sp. Gilbert (Piyo et al. 2011), Bacillus alvei NRC-14 (Abdel-Aziz et al. 2011), and Bacillus subtilis MSBN17 (Sathiyanarayanan et al. 2013).

\section{Factors affecting bioflocculant production and flocculating activity}

\section{Effect of inoculum size on bioflocculant production}

Inoculum size is a great significant factor in bioflocculant production and cell growth (Salehizadeh and Yan 2014). Salehizadeh and Shajoasadati (2001) reported that a small size of inoculum can prolong the lag phase, while the large inoculum size will create niches of the strain to overlap excessively; thus, inhibiting bioflocculant production. The effect of inoculum size on bioflocculant production in this study is shown in Table 1. An inoculum size of $4 \%$ (v/v) was optimal for bioflocculant production with flocculating activity of $80 \%$, beyond which a decrease in activity was observed. Hence, $4 \%$ (v/v) inoculum size was used for the subsequent experiments. In corroboration with our findings, Xiong et al. (2010) documented a similar report for maximal bioflocculant production by Bacillus licheniformis at $4 \%$ (v/ v) inoculum size. Also, in a study carried out by Okaiyeto et al. (2014) on a bioflocculant produced by Micrococcus sp. Leo, all the different inoculum sizes used resulted in flocculating activity of more than $80 \%$ with the maximum
Table 1 Effect of inoculum size on bioflocculant production by the test bacteria

\begin{tabular}{lrrrrr}
\hline $\begin{array}{l}\text { Inoculum } \\
\text { size }(\mathrm{v} / \mathrm{v} \%)\end{array}$ & \multicolumn{1}{l}{2} & \multicolumn{1}{l}{3} & \multicolumn{1}{l}{4} & \multicolumn{1}{l}{5} \\
\hline FA & 77.55 & 75.03 & 76.98 & 79.38 & 48.30 \\
$(\%) \pm \mathrm{SD}$ & 1.63 & 1.80 & 1.73 & 0.45 & 2.14 \\
\hline
\end{tabular}

The results are represented as mean value of triplicates \pm SD

$F A$ flocculating activity, $S D$ standard deviation

flocculating peak at $4 \%(\mathrm{v} / \mathrm{v})$. On the contrary, studies carried out on the following bacterial strains, Serratia ficaria (Gong et al. 2008), Klebsiella pneumoniae YZ-6 (Luo et al. 2014) and by consortia of Staphylococcus sp. and Pseudomonas sp. (Zhang et al. 2007) for bioflocculant production suggest inoculum size of $1 \%$ as optimum. A bioflocculant production by Aspergillus flavus and Virgibacillus sp. Rob reached the highest flocculating activity at $2 \%(\mathrm{v} / \mathrm{v})$ inoculum size (Aljuboori et al. 2013; Cosa et al. 2011).

\section{Effect of carbon source on bioflocculant production}

Carbon source plays an important role in enhancing bioflocculant production and different microorganisms prefer different carbon sources for bioflocculant production (Piyo et al. 2011). The effect of various carbon sources on bioflocculant production in this study is presented in Fig. 1. Among the different carbon sources studied, starch was the most favourable carbon source favouring bioflocculant production with a flocculating activity of $81 \%$ and maltose being the least favourable carbon source with flocculating activity of $29 \%$. Starch was then chosen as the sole carbon source for all the subsequent experiments. Similar findings were reported by $\mathrm{Li}$ et al. (2009) on bioflocculant production by Bacillus licheniformis X14, in which starch, sucrose and ethanol were the favourable carbon sources. Also, Deng et al. (2005) documented similar findings for Aspergillus parasiticus in which $96 \%$ flocculating efficiency was achieved with starch as a sole carbon source. Contrary to these findings, however, starch showed the least flocculating activity of $5 \%$ for Virgibacillus sp. Rob (Cosa et al. 2011) and completely inhibited bioflocculant production by Halomonas sp. OKOH (Mabinya et al. 2011). These findings support the observations that preferences for carbon source vary among bioflocculant-producing microorganisms (Salehizadeh and Yan 2014).

\section{Effect of nitrogen sources on bioflocculant production}

Various microorganisms require the presence of either organic or inorganic nitrogen sources for bioflocculant production (Ugbenyen et al. 2012). The effect of organic (yeast extract, tryptone, peptone, urea) and inorganic 


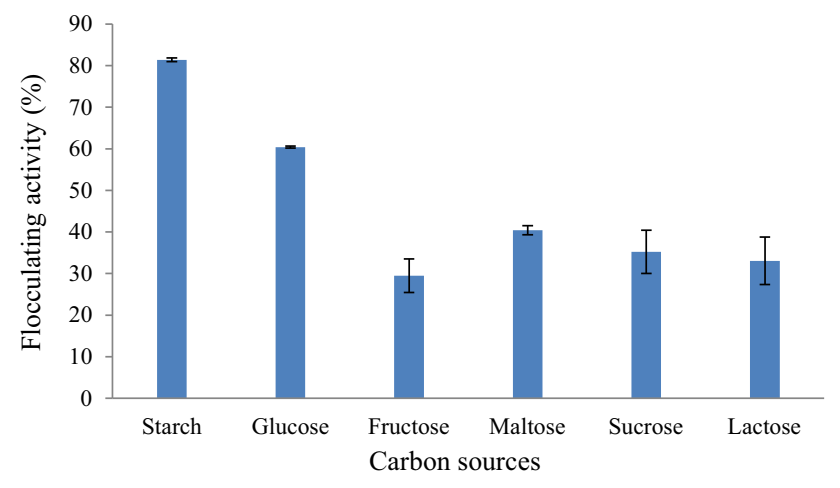

Fig. 1 Effect of carbon sources on bioflocculant production by the test bacteria

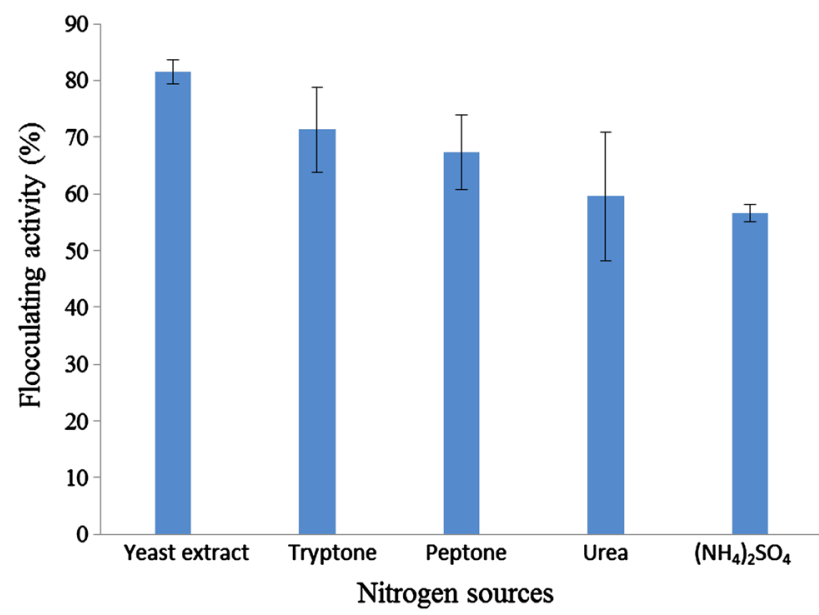

Fig. 2 Effect of nitrogen sources on bioflocculant production by the test bacteria

nitrogen sources (ammonium sulphate) on bioflocculant production by Bacillus sp. was investigated. As shown in Fig. 2, among the various nitrogen sources examined, yeast extract proved to be the best nitrogen source with the highest flocculating activity of $82 \%$ and $\left(\mathrm{NH}_{4}\right)_{2} \mathrm{SO}_{4}$ was the least favourable nitrogen source with a flocculating activity of $57 \%$. Similarly, the presence of yeast extract as sole nitrogen source showed maximal flocculating activity on a bioflocculant produced by Penicillium sp. (Liu et al. 2010). In another study carried out by Zheng et al. (2008), the production of bioflocculant by Bacillus sp. F19 showed maximal flocculating activity of $78 \%$ when yeast extract was used as a sole nitrogen source. Shadia et al. (2011) investigated the effect of various nitrogen sources on bioflocculant production by Bacillus alvei NRC-14 and reported both $\left(\mathrm{NH}_{4}\right)_{2} \mathrm{SO}_{4}$ and yeast extract to be the most effective nitrogen sources. It has been previously reported that organic nitrogen sources are easily absorbed by the cells; hence, they are most favourable for bioflocculant production when compared to inorganic nitrogen sources (Cosa et al. 2013).
Effect of the initial pH of growth medium on bioflocculant production

Initial $\mathrm{pH}$ of growth medium for bioflocculant production varies with different microorganisms (Salehizadeh and Yan 2014). The effect of initial $\mathrm{pH}$ of the growth medium on bioflocculant production was investigated at a $\mathrm{pH}$ range of 4-10 and the results are depicted in Fig. 3. In this study, bioflocculant production by Bacillus sp. remained relatively constant at a wide range of $\mathrm{pH} 4-10$ with flocculating activity between 74 and $80 \%$ as shown in Fig. 4. Optimum flocculating activity was reached at $\mathrm{pH} 8(80 \%)$. According to the findings of He et al. (2010), the flocculating activity of a bioflocculant produced by Halomonas sp. V3a' was above $80 \%$ at the $\mathrm{pH}$ range of 3-11 and the highest flocculating activity of $97 \%$ was recorded at $\mathrm{pH} 7$. The optimum initial $\mathrm{pH}$ of growth medium for the production of bioflocculants by Bacillus xn12 and Streptomyces xn17 strains was in the range of 3-10 and 3-9, respectively, with the highest flocculating activity (97\%) being observed at pH 5 for both strains (Zhang et al. 2013). Bioflocculant production by Aspergillus flavus was investigated at a $\mathrm{pH}$ range of 5-9 and the highest flocculating activity was reached at $\mathrm{pH} 7$ (Aljuboori et al. 2013), whereas Zheng et al. (2008) noted maximum flocculating activity at $\mathrm{pH} 9$ when culturing Bacillus megaterium within a wide $\mathrm{pH}$ range ranging from acidic to an alkaline $\mathrm{pH}$ of 12. Contrary to the above observations, Anabaera sp. produced a bioflocculant utilizing a very acidic medium of pH 2 (Choi et al. 1988).

\section{Effect of cations on the flocculating activity of crude bioflocculant}

Addition of cations enhance flocculating efficiency by charge neutralization and by forming bridges between particles (Salehizadeh and Shojaosadati 2001; Salehizadeh and Yan 2014). Bioflocculant efficiency is stimulated not

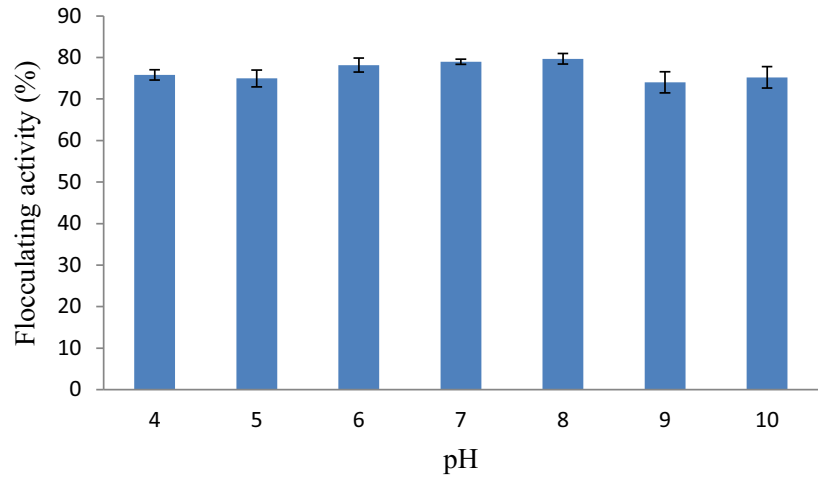

Fig. 3 Effect of initial $\mathrm{pH}$ on bioflocculant production by the test bacteria 


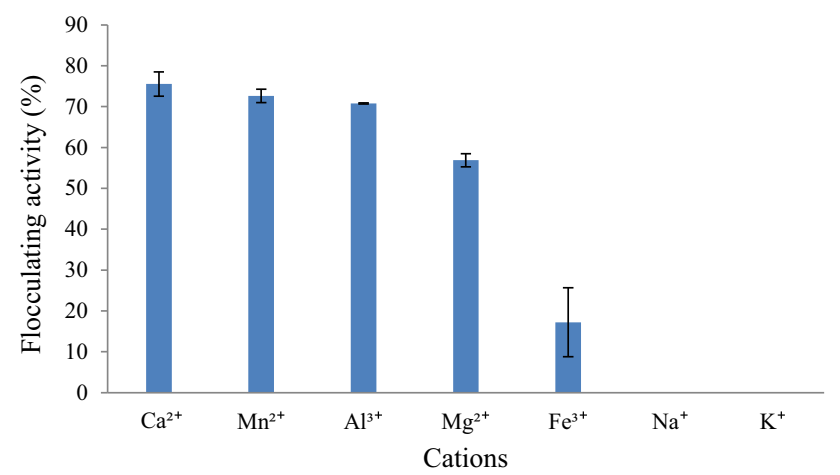

Fig. 4 Effect of cations on the flocculating activity of the bioflocculant

only by the presence and concentration of cations but is also greatly influenced by the valence of ions (Zulkeflee et al. 2012). The effects of various cations on the flocculating activity of bioflocculant produced by Bacillus sp. AEMREG4 were examined and the results are illustrated in Fig. 4. The effect of cations with various valence ions (monovalent, divalent and trivalent cations) on flocculating activity was studied. Amongst the cations tested, $\mathrm{Ca}^{2+}$ enhanced flocculating rate with the highest activity of $76 \%$, followed by $\mathrm{Mn}^{2+}, \mathrm{Al}^{3+}$ and $\mathrm{Mg}^{2+}$ at 73, 71 and $57 \%$, respectively with observed significant inhibition by $\mathrm{Fe}^{3+}$ $(17 \%)$ and complete inhibition by $\mathrm{Na}^{+}$and $\mathrm{K}^{+}$. Similar results were observed in a study conducted by Mabinya et al. (2011), whereby the flocculating activity of a bioflocculant produced by Halomonas sp. $\mathrm{OKOH}$ was increased by the addition of divalent cations with $\mathrm{Ca}^{2+}$ being the most effective. Ugbenyen and Okoh (2014) also reported that the divalent cations tested $\left(\mathrm{Ca}^{2+}, \mathrm{Mg}^{2+}\right.$,
$\mathrm{Mn}^{2+}$ ) were the best metal ions that enhanced the activity of the bioflocculant produced by the consortium of the Cobetia and Bacillus species which in turn was completely inhibited by $\mathrm{Li}^{+}$and $\mathrm{K}^{+}$. In this study, monovalent cations $\left(\mathrm{Na}^{+}\right.$and $\left.\mathrm{K}^{+}\right)$had no effect at all on flocculating activity which can be attributed to the loose bonds in its structure and consequently resulted in a decrease in floc density, size and floc resistance to shear as compared to divalent cations (Zulkeflee et al. 2012).

\section{Time course of bioflocculant production}

Pre-determined optimal culture conditions were used for the time course assay and Fig. 5 depicts the time course assay of bioflocculant production by Bacillus sp. over a cultivation period of $96 \mathrm{~h}$. Bioflocculants can be distinguished into either primary or secondary metabolites depending on the period of secretion in the culture broth (Salehizadeh and Yan 2014). The seed culture of the studied bacterial isolate prepared after $24 \mathrm{~h}$ of incubation was used for inoculation and since the bacteria is a bioflocculant-producing microbe, the small amount of the bioflocculant produced during this seed culture preparation was also utilized by the bacteria (used as a source of carbon) for growth and hence, a reduction in flocculating activity was observed at $24 \mathrm{~h}$. Subsequently, as the bacteria utilized the nutrients in the basal medium, an increase in the flocculating activity of the bioflocculant was observed and optimal production was observed at $72 \mathrm{~h}$ with flocculating activity (65\%) and beyond this cultivation period, a decline in the flocculating activity was recorded. A decline in cell growth and flocculating activity at late growth phase may be attributed to the depletion of nutrients in the production medium as well as to the production and release
Fig. 5 Time course of bioflocculant production by Bacillus sp.

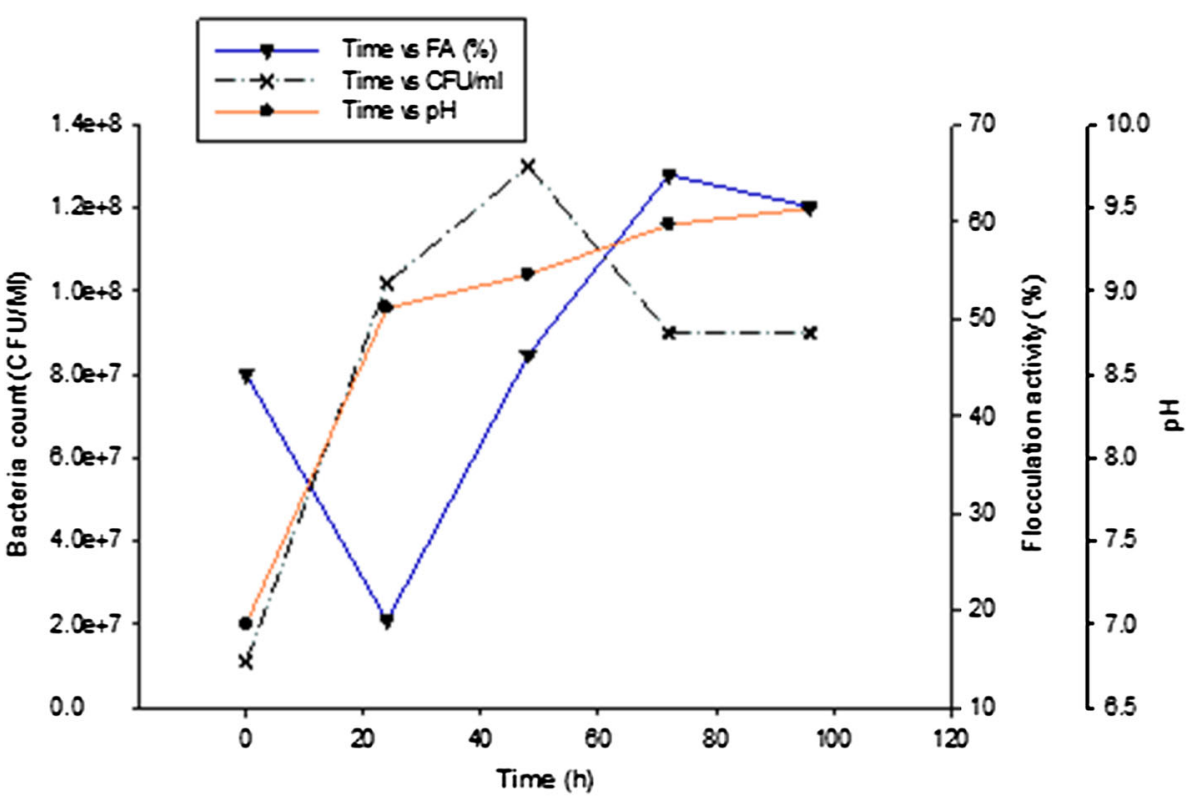


of bioflocculant-degrading enzymes which utilize the produced bioflocculant as a carbon source (Li et al. 2009; Zaki et al. 2011). Similarly, a bioflocculant produced by Serratia ficaria reached its maximum flocculating activity in the early stationary phase $(72 \mathrm{~h}$ ) and subsequently observed a slow decrease after $84 \mathrm{~h}$ which was attributed to autolysis and enzymatic activity (Gong et al. 2008). It was also observed that at the early stationary phase, there was a rapid increase in bacterial cell growth up to $48 \mathrm{~h}$ of incubation, as expressed in $\mathrm{CFU} / \mathrm{ml}$, after which a significant decrease in viable cells was observed eventually levelling off at $72 \mathrm{~h}$ with an observed gradual decrease in flocculating activity (Fig. 5). These findings indicated that the production of the bioflocculant is associated with cell growth rather than with cell autolysis (Lu et al. 2005; Gao et al. 2006). The majority of reported studies in the literature revealed that bioflocculants are produced during active growth phase of microorganisms (Prasertsan et al. 2006; Lian et al. 2008; Nwodo et al. 2013; Salehizadeh and Yan 2014). The present study seems to show a similar phenomenon. On the contrary, the bioflocculant produced by Chryseobacterium daeguense W6 was associated with cell autolysis and not cell growth (Liu et al. 2010). Running parallel to the profile of flocculating activity, the $\mathrm{pH}$ profile showed that the $\mathrm{pH}$ increased from 7.0 to 9.5 within an incubation period of $96 \mathrm{~h}$ (Fig. 5). Bioflocculant production takes place at various phases of growth of microorganisms. At various periods, production drops due to cell autolysis, metal complexing or decreased enzymatic activity depending, nevertheless, on the microbial cell culture (Lu et al. 2005; Vatansever, 2005; Cosa, 2010). A bioflocculant produced by Streptomyces sp. reached its highest flocculating activity during the logarithmic growth phase, suggesting that biosynthetic processes were responsible for the bioflocculant production process (Nwodo et al. 2012). Shih et al. (2001) reported that both cell growth and bioflocculant production by Bacillus licheniformis simultaneously reached the highest peak during the stationary phase at $96 \mathrm{~h}$. Based on the report of Cosa et al. (2011), a bioflocculant produced by Virgibacillus sp. Rob was reported to produce a bioflocculant with maximum flocculating activity reached at $96 \mathrm{~h}$ of cultivation, whereas Okaiyeto et al. (2016) documented that the bioflocculant produced by Bacillus sp. reached its maximum flocculating activity of $94.9 \%$ at $\mathrm{pH} 6.17$ attained after $72 \mathrm{~h}$.

\section{Chemical compositions analyses of the purified bioflocculant}

From Table 2, chemical analyses of the purified bioflocculant revealed it to be composed of total sugar $(79 \% \mathrm{w} / \mathrm{w})$ and total protein $(5 \% \mathrm{w} / \mathrm{w})$, suggesting that the bioflocculant is predominantly polysaccharide. Further analysis showed that the bioflocculant consisted of uronic acid
Table 2 Chemical compositions of the purified bioflocculant produced by Bacillus sp.

\begin{tabular}{lc}
\hline Component & Percentage $(\%)$ \\
\hline Total protein & 5 \\
Total sugar & 79 \\
Uronic acid & 15 \\
\hline
\end{tabular}

$(15 \% \mathrm{w} / \mathrm{w})$, which is an acidic polysaccharide. Several bioflocculants have been reported to have polysaccharide backbone as a major component, for example, the bioflocculant produced by Enterobacter aerogenes (Lu et al. 2005), the bioflocculant produced by Virgibacillus sp. Rob (Cosa et al. 2011), and the bioflocculant MBF-5 produced by Klebsiela pneumonia (Zhao et al. 2013).

\section{Functional groups analyses of purified bioflocculant}

FTIR analysis of the bioflocculant was undertaken to detect the presence of any functional groups that may contribute to its flocculating activity as shown in Fig. 6. The spectrum displayed a broad stretching intense peak at $3423 \mathrm{~cm}^{-1}$ which is a characteristic of hydroxyl group. A weak $\mathrm{C}-\mathrm{H}$ stretching vibration band was observed at $2934 \mathrm{~cm}^{-1}$. The bands at 1646 and $1455 \mathrm{~cm}^{-1}$ are characteristic of $\mathrm{C}=\mathrm{O}$ asymmetrical and weak symmetrical stretching in the carboxylate, respectively (Deng et al. 2003), which represent the presence of carboxyl group in the structure of the bioflocculant produced by Bacillus sp. The bands at 1027 and $1151 \mathrm{~cm}^{-1}$ represent the methoxyl group (Zheng et al. 2008). The sorption peak at $1239 \mathrm{~cm}^{-1}$ indicates the presence of $\mathrm{C}-\mathrm{O}$ stretching in ether or alcohol (Desouky et al. 2008). The absorption peaks around $1000-1100 \mathrm{~cm}^{-1}$ are known to be characteristic of all sugar derivatives (Zheng et al. 2008). The FTIR spectra showed the presence of carboxyl, hydroxyl and methoxyl groups, which are the preferred groups for flocculation (Zheng et al. 2008).

\section{Scanning electron microscopy (SEM) images of bioflocculant}

SEM observations were carried out to study the morphological structures of the bioflocculant before and after flocculation. Figure 7a shows a rod-shaped structure of the purified bioflocculant. Figure 7b shows Kaolin clay particles before the addition of bioflocculant and Fig. 7c shows flocculated Kaolin clay after the addition of the purified bioflocculant. Comparing b and $\mathrm{c}$, it can be deduced that the addition of the purified bioflocculant produced by the test bacteria to Kaolin clay suspension played a crucial role in connecting the scattered Kaolin particles together to form flocs and separate easily from water during the flocculation process. 


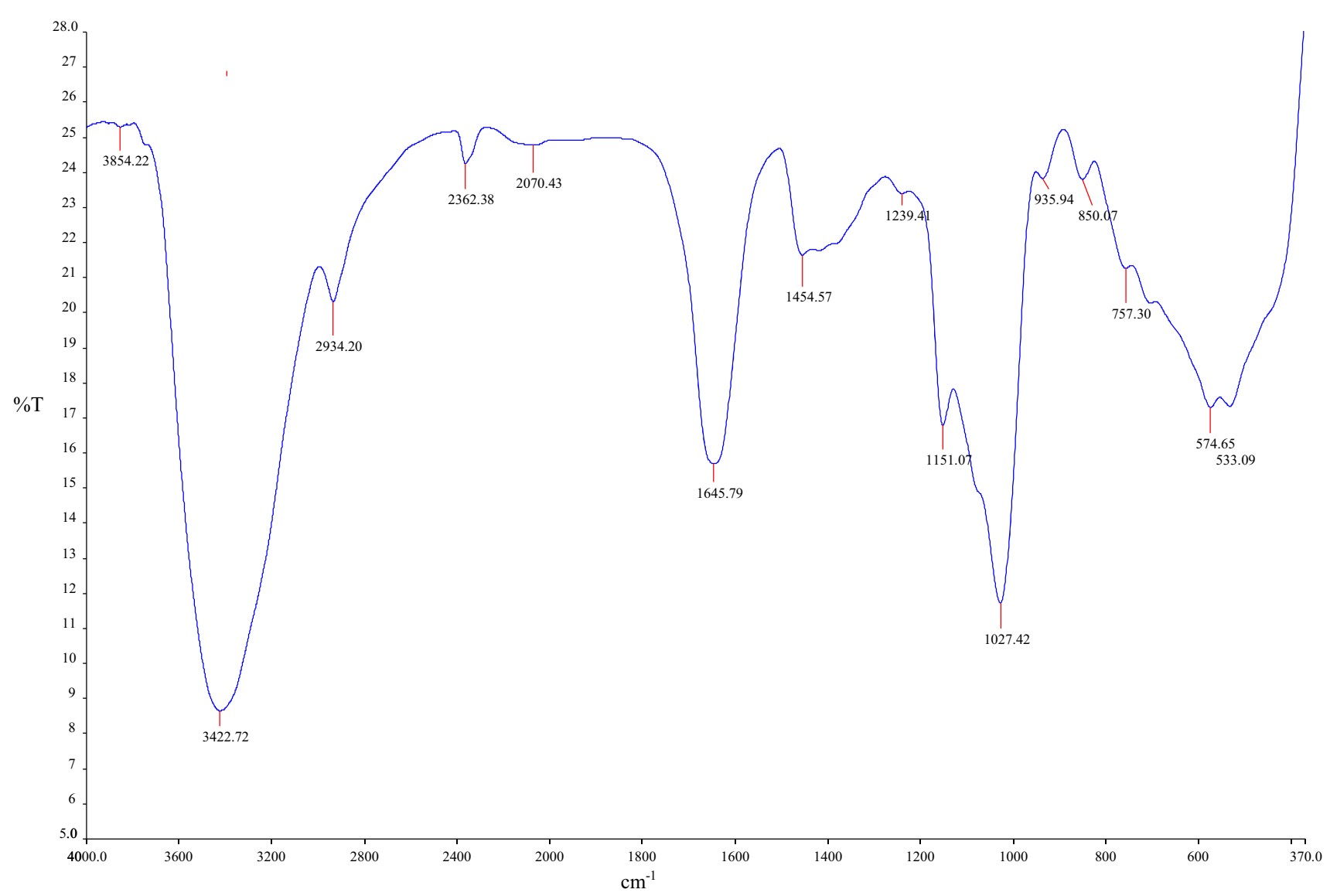

Fig. 6 Infrared spectrum of the purified bioflocculant produced by Bacillus sp.
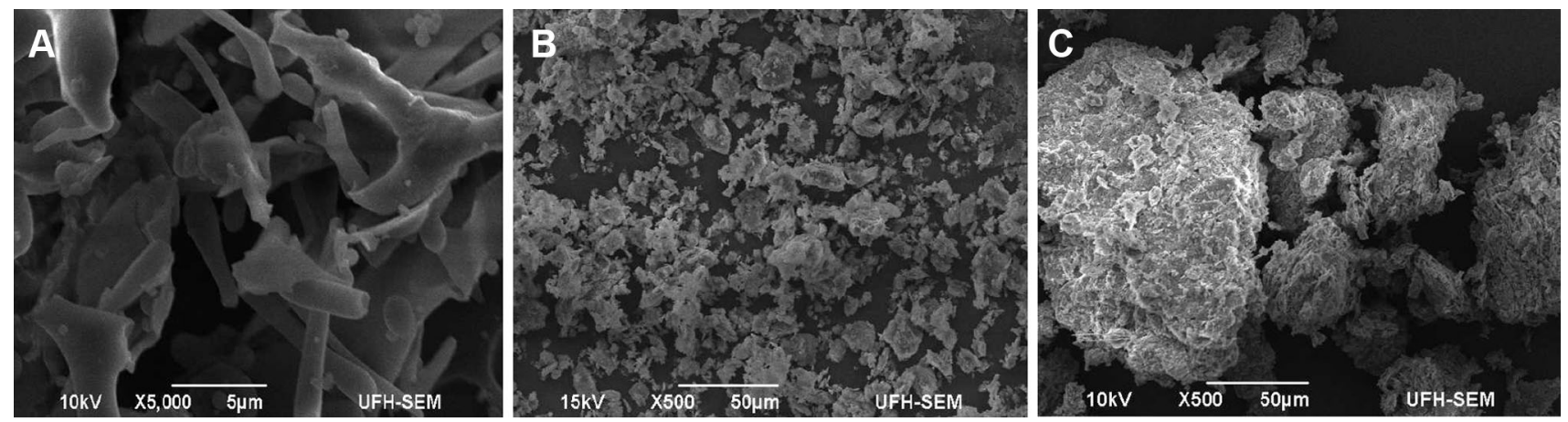

Fig. 7 SEM images of a the purified bioflocculant, b Kaolin clay particles, and $\mathbf{c}$ Kaolin clay flocculated by purified bioflocculant produced by Bacillus sp.

\section{Factors influencing the flocculating activity of the purified bioflocculant}

Effect of cations on the flocculating activity of the purified bioflocculant

The effect of cations on the flocculating activity of the purified bioflocculant was investigated as shown in Table 3. All tested cations enhanced the flocculating activity of the bioflocculant produced by Bacillus sp. AEMREG4 albeit to varying degrees: $\mathrm{Ca}^{2+}(78 \%), \mathrm{Mn}^{2+}$ (77\%), $\mathrm{Mg}^{2+}(70 \%), \mathrm{Al}^{3+}(80 \%)$ and $\mathrm{K}^{+}(60 \%)$ with $\mathrm{Na}^{+}$ $(47 \%)$ and $\mathrm{Fe}^{3+}(48 \%)$ showing the least effect (Table 3). The main cause of the poor flocculation of the bioflocculant produced by Bacillus sp. AEMREG4 in the presence of $\mathrm{Fe}^{3+}$ compared to $\mathrm{Al}^{3+}$ may be due to the synergistic effect of $\mathrm{Al}^{3+}$ with this bioflocculant and the antagonistic effect of $\mathrm{Fe}^{3+}$ with the bioflocculant; hence, resulting in high 
Table 3 Effect of cations on the flocculating activity of the purified bioflocculant

\begin{tabular}{lrrrrrrr}
\hline Cation & $\mathrm{Ca}^{2+}$ & $\mathrm{Mn}^{2+}$ & $\mathrm{Mg}^{2+}$ & $\mathrm{Al}^{3+}$ & $\mathrm{Fe}^{3+}$ & $\mathrm{Na}^{+}$ \\
\hline FA (\%) & 77.81 & 76.96 & 70.41 & 79.99 & 47.96 & 47.18 \\
\pm SD & 3.57 & 6.39 & 2.22 & 3.59 & 1.56 & 59.47 \\
\hline
\end{tabular}

The results are represented as mean value of triplicates \pm SD

$F A$ flocculating activity, $S D$ standard deviation

flocculating activity of $\mathrm{Al}^{3+}$ and lower flocculating activity of $\mathrm{Fe}^{3+}$ (Okaiyeto et al. 2015). Divalent and trivalent cations are said to have the effect of stimulating the adsorption of bioflocculant on the suspended particles by decreasing the negative charge of both the polymer and the particle (Levy et al. 1992). The bioflocculant produced by a consortium of Holomonas sp. Okoh and Micrococcus sp. Leo showed the maximum flocculating activity of $80 \%$ when $\mathrm{Al}^{3+}$ was the cation of choice (Okaiyeto et al. 2013). Stimulation of flocculating activity was observed in a bioflocculant produced by Bacillus licheniformis and Bacillus circulans when $\mathrm{Al}^{3+}$ and $\mathrm{Ca}^{2+}$ were used (Li et al. 2009).

\section{Thermal stability test of the purified bioflocculant}

The relationship between temperature and flocculating efficiency of the purified bioflocculant was examined at a temperature range of $50-100{ }^{\circ} \mathrm{C}$ for $1 \mathrm{~h}$ as depicted in Fig. 8 . The bioflocculant retained more than $74 \%$ flocculating rate when subjected to heating at $100{ }^{\circ} \mathrm{C}$ for $1 \mathrm{~h}$. Therefore, it was deduced that the bioflocculant was thermostable and its flocculating activity was not affected when the temperature was elevated. Salehizadeh and Shojaosadati (2001) reported that the presence of protein or peptide in the structure of a bioflocculant is generally linked to its sensitivity to heat and those consisting of sugars are more heat-resistant; hence, it can be concluded that the bioflocculant produced by Bacillus sp. consisted predominantly of polysaccharide. The thermal stability of this bioflocculant may be due to the presence of a hydroxyl group that is responsible in the formation of hydrogen bonds in its structure (Ugbenyen and Okoh 2014). Cosa and Okoh (2014) reported a residual flocculating activity of more than $80 \%$ for a purified bioflocculant produced by the consortium of Halobacillus sp. Mvuyo and Oceanobacillus sp. Pinky after heating at $100{ }^{\circ} \mathrm{C}$ for $1 \mathrm{~h}$, thus indicating its thermo-stability.

\section{Effect of $\mathrm{pH}$ on the flocculating activity of purified bioflocculant}

The $\mathrm{pH}$ has a great impact on flocculating activity (Cosa and Okoh 2014). The flocculating activity of the purified bioflocculant was tested within the $\mathrm{pH}$ range of $3-10$ as

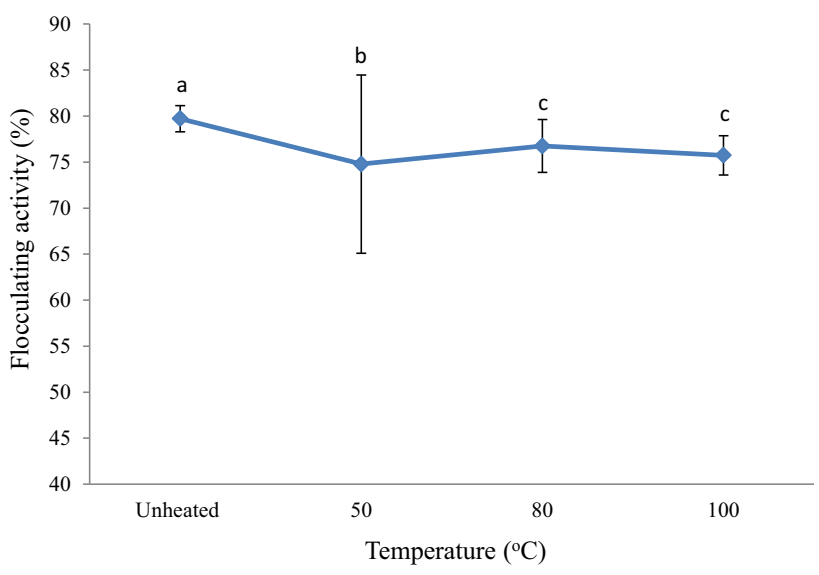

Fig. 8 Thermal stability on flocculating activity of the purified bioflocculant. Percentage of flocculating activity with different letters $(a, b$, and $c)$ are significantly $(p<0.05)$ different

illustrated in Fig. 9. A strong flocculating activity was observed over a wide range of $\mathrm{pH} 3-10$. Maximum flocculating activity was achieved at very acidic $\mathrm{pH} 3(83 \%)$ and basic pH $10(83 \%)$. This may be due to the bioflocculant exhibiting different electric states at different $\mathrm{pH}$; hence, affecting the bridging efficiency of the bioflocculant for clay powder (Yong et al. 2009). A sharp decline in flocculating activity was observed at $\mathrm{pH} 5$; this might be due to the arrangement of the surface charge which is both $\mathrm{pH}$ and temperature dependent. Hence, it can be deduced that the spatial charge arrangements for flocculation were not ambient at pH 5 (Okaiyeto et al. 2015). This bioflocculant showed excellent flocculating activity in both strong acidic and basic conditions. This studied bioflocculant flocculated at a wide $\mathrm{pH}$ range and this suggests that its industrial applicability to treat various waters or wastewaters without having to adjust the $\mathrm{pH}$ of the water thus rendering the bioflocculant cost-effective (Okaiyeto et al. 2015). Similarly, Zaki et al. (2012) also reported similar results, whereby a bioflocculant produced by Bacillus velezensis 404 was stable at the $\mathrm{pH}$ range of 3-9 and reached its maximum stability at $\mathrm{pH} 7$. Different microorganisms have been reported to produce bioflocculants with optimal activity at varying $\mathrm{pH}$ values (Wang et al. 2011). Liu et al. (2009) reported on a bioflocculant extracted from sludge, named as M-1 as showing high 


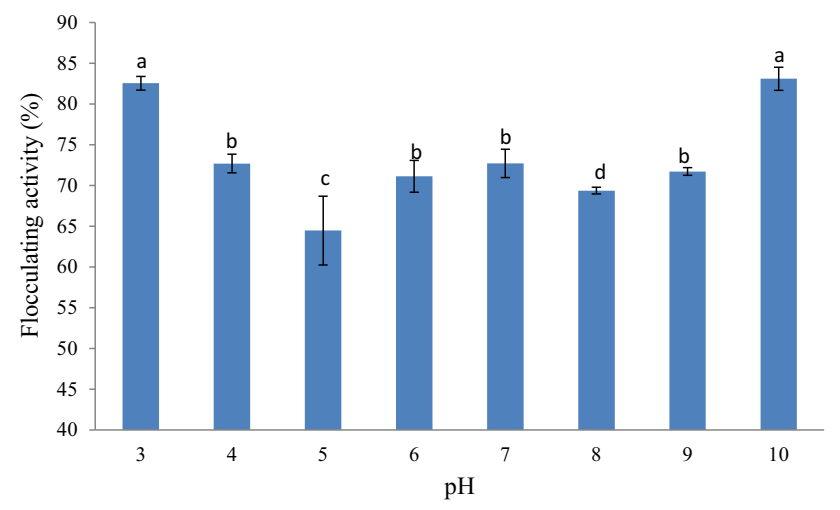

Fig. 9 Effect of $\mathrm{pH}$ on flocculating activity of the purified bioflocculant. Percentage of flocculating activity with different letters $(a, b$, $c$ and $d$ ) are significantly $(p<0.05)$ different

flocculating activity over $74 \%$ in the wider $\mathrm{pH}$ range of $3-11$, whereby the maximum flocculating activity (93\%) was achieved at $\mathrm{pH} 5$. It was stated in the literature that at low $\mathrm{pH}$ both the bioflocculant and the Kaolin particles are likely to absorb the hydrogen ions $\left(\mathrm{H}^{+}\right)$, consequently weakening the bioflocculant-Kaolin complex mediated by $\mathrm{Ca}^{2+}$ and a similar effect was also observed at high $\mathrm{pH}$ values due to $\mathrm{OH}-$ ions ( $\mathrm{He}$ et al. 2010).

\section{Conclusions}

This study demonstrated the potential of Bacillus sp. isolated from water samples of Thyume River for bioflocculant production when starch, yeast extract and $\mathrm{Ca}^{2+}$ were used as sole carbon, nitrogen and cation sources, respectively. The bioflocculant showed outstanding flocculating activity in both strong acidic and basic conditions. The production of the bioflocculant produced by Bacillus sp. was found to be associated with cell growth. The FTIR spectrum showed the presence of carboxyl, hydroxyl and methoxyl groups in its molecular chain which are important for flocculation. This bioflocculant consists mainly of polysaccharide which is elucidated by its thermo-stability over a wide range of temperature; a characteristic feature portends its industrial applicability and further studies on practical applications for large-scale production of the bioflocculant is part of on-going research in our laboratory.

Acknowledgements We are grateful to the National Research Foundation (NRF) of South Africa, the Medical Research Council of South Africa and University of Fort Hare for financial support.

\section{Compliance with ethical standards}

Conflict of interest No conflict of interest was declared.
Open Access This article is distributed under the terms of the Creative Commons Attribution 4.0 International License (http:// creativecommons.org/licenses/by/4.0/), which permits unrestricted use, distribution, and reproduction in any medium, provided you give appropriate credit to the original author(s) and the source, provide a link to the Creative Commons license, and indicate if changes were made.

\section{References}

Abdel-Aziz SM, Hamed HA, Mouafi FE, Abdelwahed NAM (2011) Extracellular metabolites produced by a novel strain, Bacillus alvei NRC-14: 3. synthesis of a bioflocculant that has chitosanlike structure. Life Sci J 8:883-890

Aljuboori RAH, Idris A, Abdullah N, Mohamed R (2013) Production and characterization of a bioflocculant produced by Aspergillus flavus. Biores Technol 127:489-493

Arezoo C (2002) The potential role of aluminium in Alzheimer's disease. Nephrol Dial Transpl 17:17-20

Chaplin MF, Kennedy JF (1994) Carbohydrate analysis, 2nd edn. Oxford University Press, New York

Choi CW, Yoo SA, Oh IH, Park SH (1988) Characterization of an extracellular flocculating substance produced by a planktonic cyanobacterium, Anabaena sp. Biotechnol Lett 20:643-646

Cosa S (2010) Assessment of bioflocculant production by some marine bacteria isolated from the bottom sediment of Algoa Bay. Masters Dissertation, University of Fort Hare, South Africa

Cosa S, Okoh AI (2014) Bioflocculant production by consortium of two bacterial species and its potential application in industrial wastewater and water treatment. Pol J Environ Stud 23:689-696

Cosa S, Mabinya LV, Olaniran AO, Okoh OO, Bernard K, Deyzel S, Okoh AI (2011) Bioflocculant production by Virgibacillus sp. Rob isolated from the bottom sediment of Algoa Bay in the Eastern Cape, South Africa. Molecules 16:2431-2442

Cosa S, Ugbenyen MA, Mabinya LV, Rumbold K, Olaniran AO, Aghdasi F, Okoh AI (2013) A marine bacterium, Oceanobacillus sp. pinky, isolated from Algoa Bay sediment produces a thermostable glycoprotein flocculant. Afr J Biotechnol 12:4135-4146

Dearfield KL, Abernathy CO, Ottley MS, Brantner JH, Hayes PF (1988) Acrylamide: its metabolism, developmental and reproductive effects, genotoxicity and carcinogenicity. Mutat Res 195:45-77

Deng B, Bai B, Hu M (2003) Characteristics of a bioflocculant produced by Bacillus mucilaginosus and it's used in starch wastewater treatment. Appl Microbiol Biotechnol 60:588-593

Deng S, Yu G, Ting YP (2005) Production of a bioflocculant by Aspergillus parasiticus and its application in dye removal. Colloids Surf B 44:179-186

Desouky AM, Haleem AE, Roda FT, Thourya M, Sidra M, Fatima H (2008) Isolation and characterization of extracellular bioflocculants produced by bacteria isolated from Quatari ecosystems. Pol J Microbiol 57:231-239

Gao J, Bao HY, Xin MX, Liu YX, Li Q, Zhang YF (2006) Characterization of a bioflocculant from a newly isolated Vagococcus sp. W31. J Zhejiang Uni Sci B 7:186-192

Gong W, Wang S, Sun X, Liu X, Yue Q, Gao B (2008) Bioflocculant production by culture of Serratia ficaria and its application in wastewater treatment. Biores Technol 99:4668-4674

He J, Zou J, Shao Z, Zhang J, Liu Z, Yu Z (2010) Characteristics and flocculating mechanism of a novel bioflocculant HBF-3 produced by deep-sea bacterium mutant Halomonas sp. V3a. World J Microbiol Biotechnol 26:1135-1141 
Kurane R, Hatamochi K, Kiyohara T, Hirao M, Taniguchi Y (1994) Production of a bioflocculant by Rhodococcus erythropolis S-1 grown on alcohols. Biosci Biotechnol Biochem 58:428-429

Lachhwani P (2005) Studies on Polymeric Bioflocculant Producing Microorganisms. Master dissertation, Thapar Institute of Engineering and Technology, Patiala, India

Levy N, Magdasi S, Bar-Or Y (1992) Physico-chemical aspects in flocculation of bentonite suspensions by a cyanobacterial. Water Res 26:249-254

Li Z, Zhong S, Lei H, Chen R, Yu Q, Li H (2009) Production of a novel bioflocculant by Bacillus licheniformis X14 and its application to low temperature drinking water treatment. Biores Technol 100:3650-3656

Lian B, Chen Y, Zhao J, Teng HH, Zhu LJ, Yuan S (2008) Microbial flocculation by Bacillus mucilaginosus: applications and mechanisms. Biores Technol 99:4825-4831

Liu W, Yuan H, Yang J, Li B (2009) Characterization of bioflocculants from biologically aerated filter backwashed sludge and its application in dying wastewater treatment. Bioresour Technol 100:2629-2632

Liu W, Wang K, Li B, Yuan HL, Yang JS (2010) Production and characterization of an intracellular bioflocculant by Chryseobacterium daeguense W6 cultured in low nutrition medium. Biores Technol 101:1044-1048

Lowry OH, Rosebrough NJ, Farr AL, Randall RJ (1961) Protein measurement with the Folin phenol reagent. J Biol Chem 193:265-275

Lu WY, Zhang T, Zhang DY, Li CH, Wen P, Du LX (2005) A novel bioflocculant produced by Enterobacter aerogenes and its use in defecating the trona suspension. Biochem Eng J 27:1-7

Luo Z, Chen L, Chen C, Zhang W, Liu M, Han Y, Zhou J (2014) Production and characteristics of a bioflocculant by Klebsiella pneumoniae YZ-6 isolated from human saliva. Appl Biochem Biotechnol 173:1282-1292

Mabinya LV, Cosa S, Mkwetshana N, Okoh AI (2011) Halomonas sp. $\mathrm{OKOH}-$ a marine bacterium isolated from the bottom sediment of Algoa Bay-produces a polysaccharide bioflocculant: partial characterization and biochemical analysis of its properties. Molecules 16:4358-4370

Makapela B, Okaiyeto K, Ntozonke N, Nwodo UU, Green E, Mabinya LV, Okoh AI (2016) Assessment of Bacillus pumilus isolated from fresh water milieu for bioflocculant production. Appl Sci 6:211-230

Nwodo UU, Agunbiade MO, Green E, Mabinya LV, Okoh AI (2012) A freshwater Streptomyces, isolated from Tyume river, produces a predominantly extracellular glycoprotein bioflocculant. Int $\mathrm{J}$ Mol Sci 13:8679-8695

Nwodo UU, Agunbiade MO, Green E, Nwamadi M, Rumbold K, Okoh AI (2013) Characterization of an exopolymeric flocculant produced by a Brachybacterium sp. Materials 6:1237-1254

Nwodo UU, Green E, Mabinya LV, Okaiyeto K, Rumbold K, Obi CL, Okoh AI (2014) Bioflocculant production by a consortium of Streptomyces and Cellulomonas species and media optimization via surface response model. Colloids Surf B 116:257-264

Okaiyeto K, Nwodo UU, Mabinya LV, Okoh AI (2013) Characterization of a bioflocculant produced by a consortium of Halomonas sp. Okoh and Micrococcus sp. Leo. Int J Environ Res Public Health 10:5097-5110

Okaiyeto K, Nwodo UU, Mabinya LV, Okoh AI (2014) Evaluation of the flocculation potential and characterization of bioflocculant produced by Micrococcus sp. Leo. Appl Biochem Microbiol 50:601-608

Okaiyeto K, Nwodo UU, Mabinya LV, Okoli AS, Okoh AI (2015) Characterization of a bioflocculant (MBF-UFH) produced by Bacillus sp. AEMREG7. Int J Mol Sci 16:12986-13003
Okaiyeto K, Nwodo UU, Mabinya LV, Okoli AS, Okoh AI (2016) Evaluation of flocculating performance of a thermostable bioflocculant produced by marine Bacillus sp. Environ Technol 37:1829-1842

Piyo N, Cosa S, Mabinya LV, Okoh AI (2011) Assessment of bioflocculant production by Bacillus sp. Gilbert, a marine bacterium isolated from the bottom sediment of Algoa Bay. Mar Drugs 9:1232-1242

Prasertsan P, Dermlim W, Doelle H, Kennedy JF (2006) Screening, characterization and flocculating property of carbohydrate polymer from newly isolated Enterobacter cloacae WD7. Carbohydr Polym 66:289-297

Salehizadeh H, Shojaosadati SA (2001) Extracellular biopolymeric flocculants: recent trends and biotechnological importance. Biotechnol Adv 19:371-385

Salehizadeh H, Shojaosadati SA (2003) Removal of metal ions from aqueous solution by polysaccharide produced from Bacillus firmus. Water Res 37:4231-4235

Salehizadeh H, Yan N (2014) Recent advances in extracellular biopolymer flocculants. Biotechnol Adv 32:1506-1522

Sathiyanarayanan G, Seghal Kiran G, Selvin J (2013) Synthesis of silver nanoparticles by polysaccharide bioflocculant produced from marine Bacillus subtilis MSBN17. Colloids Surf B 102:13-20

Shadia MAA, Hoda AH, Foukia EM, Nayera AMA (2011) Extracellular metabolites produced by a novel strain, Bacillus alvei NRC14: 3. synthesis of a bioflocculant that has chitosan-like structure. J Life Sci 8:883-890

Shih IL, Van YT, Yeh LC, Lin HG, Chang YN (2001) Production of a biopolymer flocculant from Bacillus licheniformis and its flocculation properties. Biores Technol 78:267-272

Ugbenyen AM, Okoh AI (2014) Characteristics of a bioflocculant produced by a consortium of Cobetia and Bacillus species and its application in the treatment of wastewaters. Water SA 40:139-144

Ugbenyen A, Cosa S, Mabinya L, Babalola OO, Aghdasi F, Okoh AI (2012) Thermostable bacterial bioflocculant produced by Cobetia spp. isolated from Algoa Bay (South Africa). Int J Environ Res Public Health 9:2108-2120

Vatansever A (2005) Bioflocculation of activated sludge in relation to Calcium concentration Masters Dissertation, Middle East Technical University, Turkey

Wang L, Ma F, Qu Y, Sun D, Li A, Guo J, Yu B (2011) Characterization of a compound bioflocculant produced by mixed culture of Rhizobium radiobacter F2 and Bacillus sphaeicus F6. World J Microbiol Biotechnol 27:2559-2565

Xiong Y, Wang Y, Yu Y, Li Q, Wang H, Chen R, He N (2010) Production and characterization of a novel bioflocculant from Bacillus licheniformis. Appl Environ Microbiol 76:2778-2782

Yim JH, Kim SJ, Ahn SH, Lee HK (2007) Characterization of a novel bioflocculant, p-KG03, from a marine dinoflagellate, Gyrodinium impudicum KG03. Biores Technol 98:361-367

Yong P, Bo S, Yu Z (2009) Research on flocculation property of bioflocculant PGa21 Ca. Mod Appl Sci 3:106-112

Zaki S, Farag S, Elreesh GA, Elkady M, Nosier M, Hallem DAE (2011) Characterization of bioflocculants produced by bacteria isolated from crude petroleum oil. Int J Environ Sci Technol 8:831-840

Zaki S, Elkady MF, Farag S, Abd-El-Haleem D (2012) Characterization and flocculation properties of a carbohydrate bioflocculant from a newly isolated Bacillus velezensis 40B. J Environ Biol 34:51-58

Zhang ZQ, Lin B, Xia SQ, Wang XJ, Yang AM (2007) Production and application of a novel bioflocculant by multiple-microorganism consortia using brewery wastewater as carbon source. J Environ Sci 19:667-673 
Zhang ZQ, Xia SQ, Zhao SQ, Zhang JF (2010) Characterization and flocculation mechanism of high efficiency microbioflocculant TJ-F1 from Proteus mirabilis. Colloids and Surf B 75:247-251

Zhang CL, Cui YN, Wang Y (2013) Bioflocculants produced by Gram-positive Bacillus xn12 and Streptomyces xn17 for swine wastewater application. Chem Biochem Eng Q 27:245-250

Zhao H, Liu H, Zhou J (2013) Characterization of a bioflocculant MBF-5 by Klebsiella pneumoniae and its application in Acanthamoeba cysts removal. Biores Technol 137:226-232

Zheng Y, Ye ZL, Fang XL, Li YH, Cai WM (2008) Production and characteristics of a bioflocculant produced by Bacillus sp. F19. Biores Technol 99:7686-7691
Zouboulis AI, Chai XL, Katsoyiannis AI (2004) The application of bioflocculant for the removal of humic acids from stabilized landfill leachates. J Environ Manage 70:30-35

Zulkeflee Z, Aris AZ, Shamsuddin ZH, Yusoff MK (2012) Cation dependence, $\mathrm{pH}$ tolerance, and dosage requirement of a bioflocculant produced by Bacillus spp. UPMB13: flocculation performance optimization through kaolin assays. Sci World J. doi:10. 1100/2012/495659 